\title{
Study of Selected Morphologic, Structural and Optical Effects of Silver Coated CBD-CdS Thin Films
}

\author{
Angel Roberto Torres-Duarte, ${ }^{1}$ Horacio Antolín Pineda-Leon, ${ }^{1,2}$ \\ Aned de Leon, ${ }^{3, *}$ Ramón Ochoa-Landín ${ }^{4}$ and Santos Jesús Castillo ${ }^{1}$ \\ ${ }^{1}$ Departamento de Investigación en Física, Universidad de Sonora, Apdo. Postal 5-088, \\ CP. 83000, Hermosillo, Sonora, México \\ ${ }^{2}$ Departamento de Matemáticas, Universidad de Sonora, CP. 83000, Hermosillo, Sonora, México \\ ${ }^{3}$ Departamento de Ciencias Químico Biológicas, Universidad de Sonora, C.P. 83000, Hermosillo, Sonora, México. \\ ${ }^{4}$ Departamento de Física, Universidad de Sonora, CP. 83000, Hermosillo, Sonora, México \\ *Corresponding author: E-mail: aned.deleon@unison.mx
}

Received: 05-08-2020

\begin{abstract}
This work focused on comparing cadmium sulphide (CdS) thin films with and without CdS silver aggregates (CdS:Ag) deposited on the surface. We report absorption and transmission responses. Using the Tauc method, we obtained direct band gap energies with values of $2.50(\mathrm{CdS})$ and $2.49 \mathrm{eV}(\mathrm{CdS}: \mathrm{Ag})$. We performed a scanning electron microscope characterization at different magnifications were cluster formations with granular shapes were observed. The highest magnification of 50,000 $\times$ showed silver clusters as shiny granulates, which were confirmed by microprobe elemental mapping at a magnification of 18,000×. Energy Dispersive Spectroscopy revealed that the light composition of the silver clusters was the unique difference from the CdS thin film. X-Ray Diffraction results only detected the hexagonal CdS pattern, but not that of silver. The crystallite size was of around $13 \mathrm{~nm}$. A Surface-Enhanced Ramman Scattering effect was observed upon the silver coating of the CdS thin film at $293.3 \mathrm{~cm}^{-1}$.
\end{abstract}

Keywords: CdS thin films; Ag coated film; CBD; characterization

\section{Introduction}

Cadmium sulphide has been applied in some optoelectronical devices, window layers, ${ }^{1}$ and on thin film solar cells due to their suitable band gaps, absorption coefficient and high optical transparency in the visible light range spectrum, in addition to being low-cost. ${ }^{2,3}$ However, upon direct contact, CdS is a hazardous material for living beings. ${ }^{4}$ It has been reported that silver ( $\mathrm{Ag}$ ) has no negative effect on humans. ${ }^{5}$ This work focuses on applying a silver coating on a CdS thin film and characterizing: a) the pure $\mathrm{CdS}$ and $\mathrm{b}$ ) the silver coated CdS thin films. At this point, we examined if the properties were modified upon the presence of silver and how. The coating we examined in this case was formed of discrete clusters.

The synthesis methods of CdS are pulsed laser deposition (PLD), ${ }^{6}$ molecular beam epitaxy (MBE), ${ }^{7}$ thermal evaporation, sputtering, chemical vapor deposition (CVD), ${ }^{8}$ chemical bath deposition (CBD), ${ }^{9}$ among others. In this work we chose CBD since it is the most simple, fast and cheap technique that yields thin films with similar properties than those obtained with more complicated and expensive methodologies. ${ }^{10}$

In 2000, SJ Castillo et al. diffused metallic indium on a CdS thin film. ${ }^{11}$ In 2010, A. de Leon et al. theoretically studied the interactions between CdS and glycine. ${ }^{12}$ In 2011, A. Apolinar-Iribe et al. synthesized hexagonal CdS thin films with acetylacetone as complexing agent through CBD. ${ }^{13}$ In 2017, M. Ruiz-Preciado et al. developed criteria to adjust the growth of both, CdS and CdTe Thin Films elaborated by the PLD technique. ${ }^{14}$ In 2011, S. Rengaraj et al. developed a solution phase synthesis method for cubic CdS hollow microspheres of around $2.5 \mu \mathrm{m}$ in diameter, 
with photocatalytic activity. ${ }^{15}$ In 2019 , Chao Xu et al. predicted the formation of clusters of combined elements including cadmium, silver, sulfur and oxygen with promising semiconducting and photocatalytic activity. ${ }^{16}$ T. Zhai et al. have synthesized CdS micro/nanowires, nanorods, nanotubes and other nanostructures for applications in electronic and optoelectronic devices. ${ }^{17}$

J. Kaur et al. synthesized CdSe thin films doped with $\mathrm{Ag}$ and analyzed some morphological, optical and structural properties. ${ }^{18}$ Furthermore, CdS thin films were prepared via thermal evaporation and then immersed on a silver nitrate $\left(\mathrm{AgNO}_{3}\right) .{ }^{19}$

\section{Experimental}

In this section, we explain the CdS thin film and the silver coated CdS thin film recipes. The cadmium source for the CdS thin film, was $10 \mathrm{~mL}$ of a $0.1 \mathrm{M}$ solution of cadmium nitrate, $\mathrm{Cd}\left(\mathrm{NO}_{3}\right)_{2}$. To this solution we added 20 $\mathrm{mL}$ of a $0.5 \mathrm{M}$ solution of the complexing agent, sodium citrate, $\mathrm{Na}_{3} \mathrm{C}_{6} \mathrm{H}_{5} \mathrm{O}_{7}$. To control the $\mathrm{pH}$ of the reaction, we used $10 \mathrm{~mL}$ of a $0.3 \mathrm{M}$ solution of potassium hydroxide $(\mathrm{KOH})$. Afterwards, we poured $10 \mathrm{~mL}$ of a $0.5 \mathrm{M}$ solution of thiourea, $\mathrm{CS}\left(\mathrm{NH}_{2}\right)_{2}$, as the sulfur source. Next, we included $5 \mathrm{~mL}$ of a pH 11 buffer, $\mathrm{NH}_{4} \mathrm{OH} / \mathrm{NH}_{4} \mathrm{Cl}$. Finally, we added deionized water to an afforated volume of $95 \mathrm{~mL}$. Furthermore, we vertically immersed 4 Corning brand soda lime glass substrates in the reactor at $70{ }^{\circ} \mathrm{C}$ for 30 min. After this, we obtained $4 \mathrm{CdS}$ thin films deposited on the glass substrate. Two of these samples were used for characterization. The other two were reimmersed on a colloidal silver suspension at $24^{\circ} \mathrm{C}$ for $20 \mathrm{~min}$. The colloidal silver suspension was prepared with $2.5 \mathrm{~mL}$ of Microdyn brand commercial colloidal silver $(0.082 \%$ volume of colloidal silver). Two silver coated $\mathrm{CdS}$ thin films were obtained.

The CdS and silver coated CdS thin films were characterized through different devices. Transmission and adsorption characterizations were performed with a UV-Vis Nanodrop 2000 ThermoScientific brand spectrophotometer. SEM and EDS characterizations were carried out with JEOL JSM-7800F equipment. The XRD characterization was realized with a RIGAKU Dmax2100 equipment. The Raman characterization was done with Dilor Labram II equipment at an excitation line of $632.8 \mathrm{~nm}$.

\section{Results and Discussion}

As it can be seen on Fig. 1, the CdS thin film has a low absorption between 553 and $1100 \mathrm{~nm}$. While it has an absorption edge at wavelengths lower than $496 \mathrm{~nm}$. On the other hand, the transmission graph for this thin film shows a transmission higher than $70 \%$ for wavelengths higher than $553 \mathrm{~nm}$. The CdS:Ag thin film has a low absorption

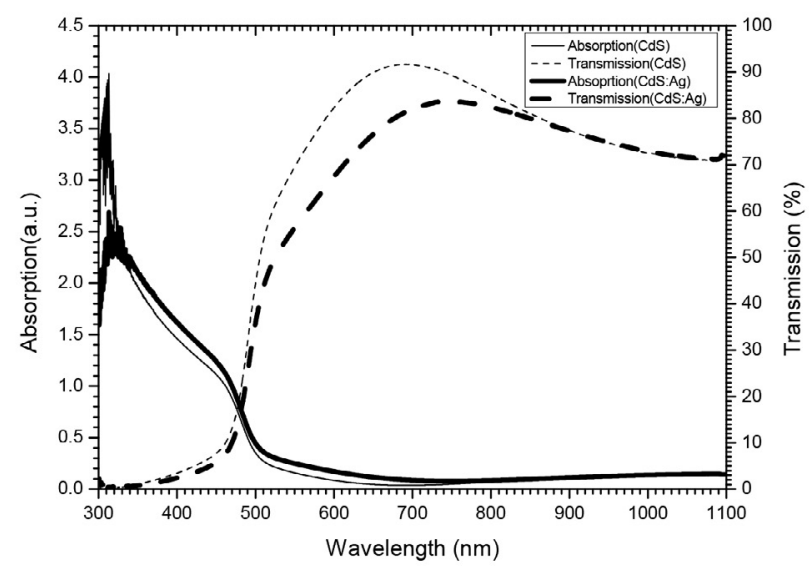

Figure 1. Absorption and transmission responses for CdS and silver coated CdS thin films.

between 615 and $1100 \mathrm{~nm}$. It has an absorption edge at wavelengths lower than $498 \mathrm{~nm}$. On the other hand, the transmission graph for this thin film shows a transmission higher than $70 \%$ for wavelengths higher than $615 \mathrm{~nm}$. The transmission curves between CdS and CdS:Ag thin films differ from 492 to $894 \mathrm{~nm}$, where the CdS layer coated with silver decreases its transmission mildly. It should be noted that CdS thin films are yellowish, while the resulting $\mathrm{CdS}$ thin films coated with silver change to an amber-like color.

We processed the optical absorption data generated on Fig. 1 in order to obtain Fig. 2 where we evaluated the direct band gaps through the Tauc method. ${ }^{20}$ We performed linear regressions (see supplementary material) to both curves on Fig. 2 to obtain the band gap and the error propagation. The direct band gaps were of $2.49 \pm 0.007 \mathrm{eV}$ and $2.50 \pm 0.009 \mathrm{eV}$. This reduction can be interpreted as a very localized doping on the surface. These energy band gap values correspond to 496 and $498 \mathrm{~nm}$ for the CdS and silver coated CdS thin film, respectively. On the study performed by Shah et al., ${ }^{19}$ the CdS thin film reached a maxi-

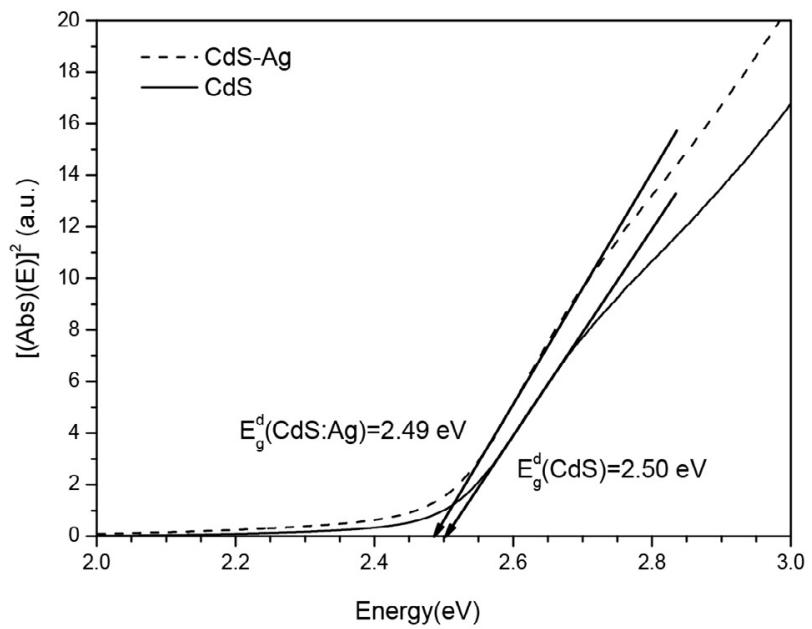

Figure 2. Direct band gaps obtained via the Tauc method. 


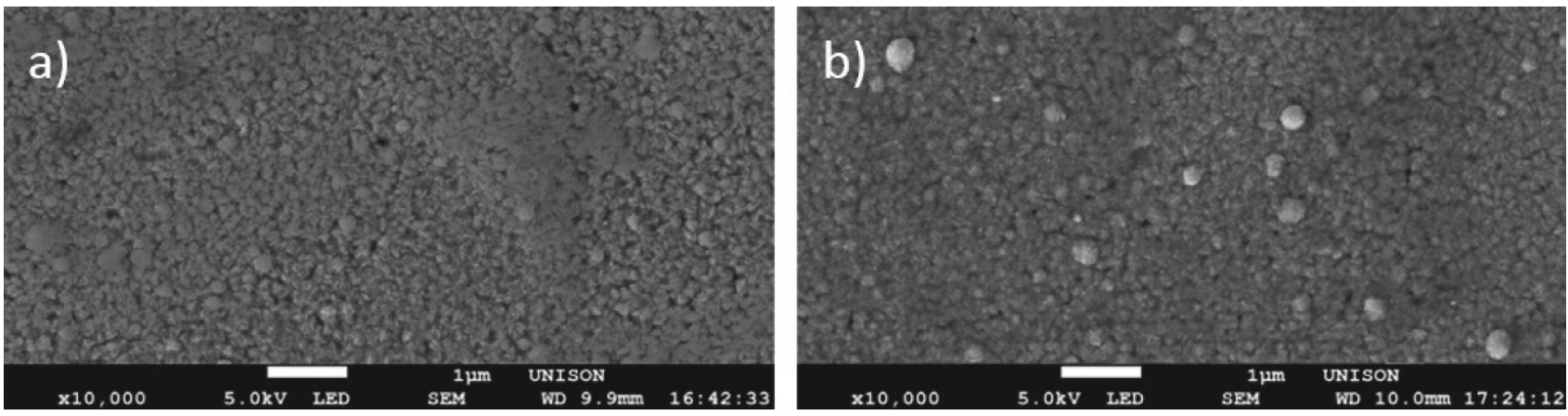

Figure 3. SEM $1 \mu \mathrm{m}$ images at a magnification of $10,000 \times$ of a) CdS thin film, b) silver coated thin film.
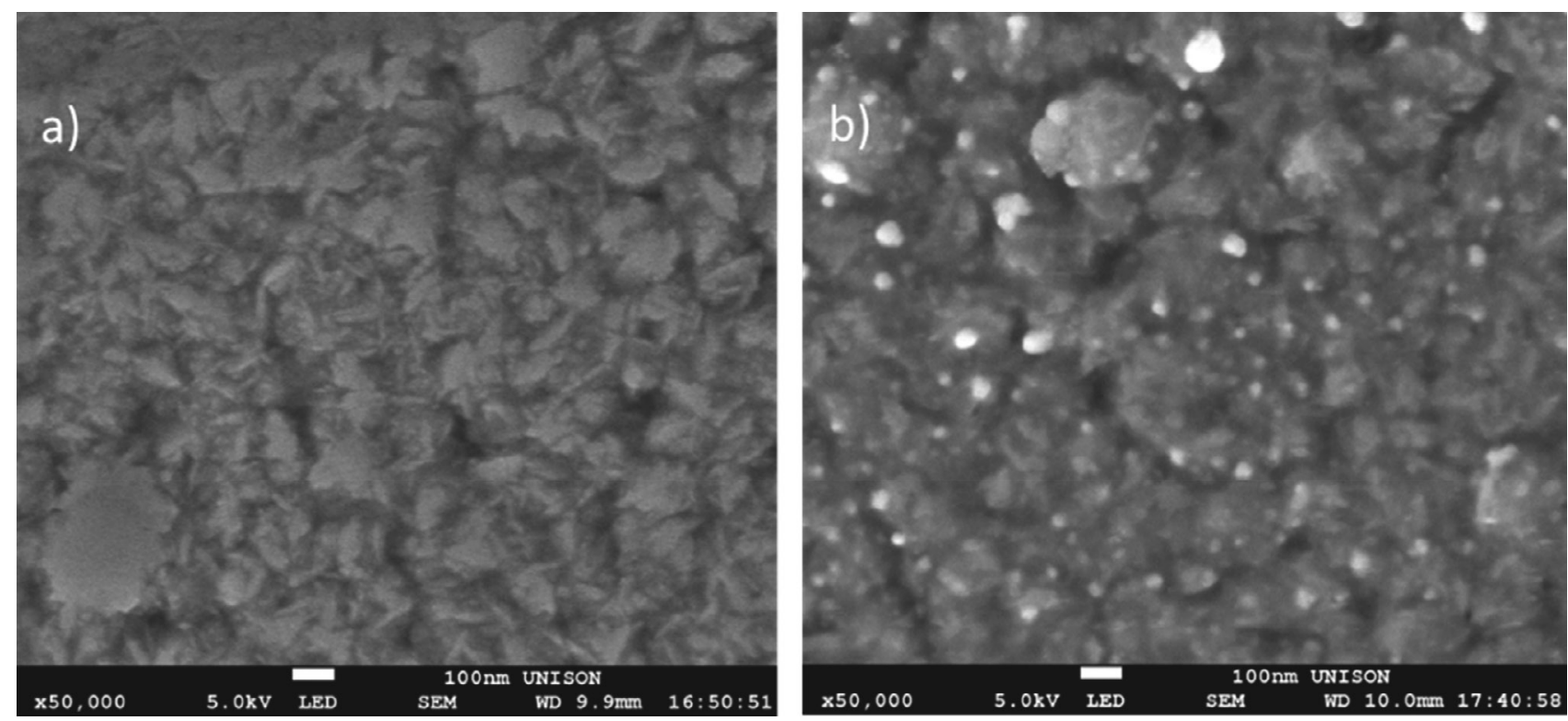

Figure 4. SEM $100 \mathrm{~nm}$ images at a magnification of 50,000x of a) CdS thin film, b) silver coated thin film.

mum transmission value of $80 \%$. Our results show that beyond $589 \mathrm{~nm}$ the transmission values were higher than $80 \%$ and up to $92 \%$ on the visible region.

The morphologic studies performed by the SEM technique show differences on the surfaces of the films.
Figure 3 depicts a scale of $1 \mu \mathrm{m}$ at a magnification of $10,000 \times$. Part a) corresponds to the CdS thin film where a flat background is observed with some imperfections. Part b) corresponds to the silver coated CdS thin film. Additional isolated spheres appeared, which we expect to be
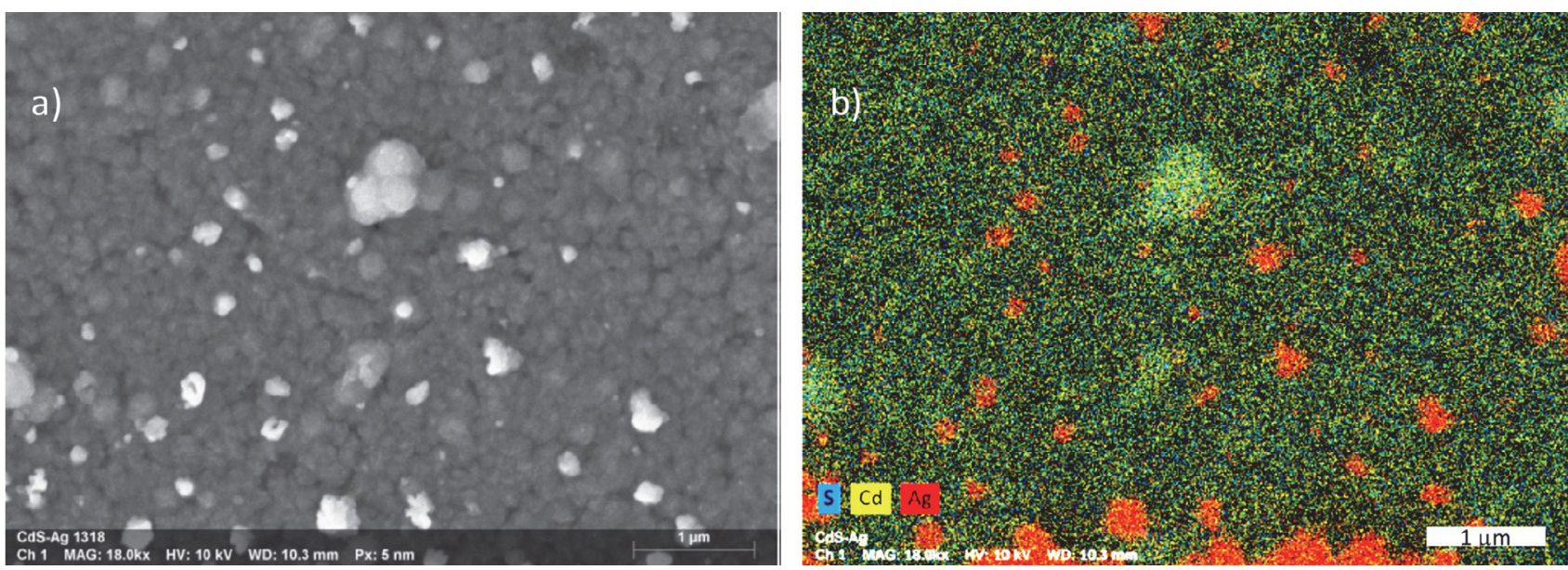

Figure 5. Silver coated thin film images: a) SEM $1 \mu \mathrm{m}$ at a magnification of $18,000 \times$, b) EDS coupled to SEM surface mapping. 
silver since the CdS thin films were immersed in a colloidal silver suspension.

Figure 4 displays the films of Figure 3 at a scale of 100 $\mathrm{nm}$ and a magnification of 50,000×. Part a) corresponds to the CdS thin film with flat background and granular formations (CdS clusters). Part b) corresponds to the silver coated CdS thin film. We presume that the small, shiny grains formed were $\mathrm{Ag}$ aggregates.

An elemental mapping was carried out on the bilayer of the silver coated CdS thin film with the distributions of the elements sulphur, cadmium and silver. Part a) corresponds to a morphologic image on a gray scale formed by secondary electrons. Part b) is formed by a EDS energy detector coupled to the SEM generating a surface mapping of the indicated element distribution. As it can be seen, the bright spots have a high composition of silver as indicated on part b) of Figure 7. Related theoretical research can be found with this configuration of materials on the scientific literature by Chao Xu et al. ${ }^{16}$ The research made by Shah et al. obtained noticeably different morphology and did not present the formation of silver aggregates. ${ }^{19}$

EDS measurements were performed to both films. The distribution of elements was portrayed on Figure 6, where the curves of both films are superposed. The CdS thin film curve has well-defined signals for oxygen, sodium, silicon, sulphur, cadmium and other elements. Cadmium and Sulphur signals are due to the film, yet the rest of them are originated from the substrate.

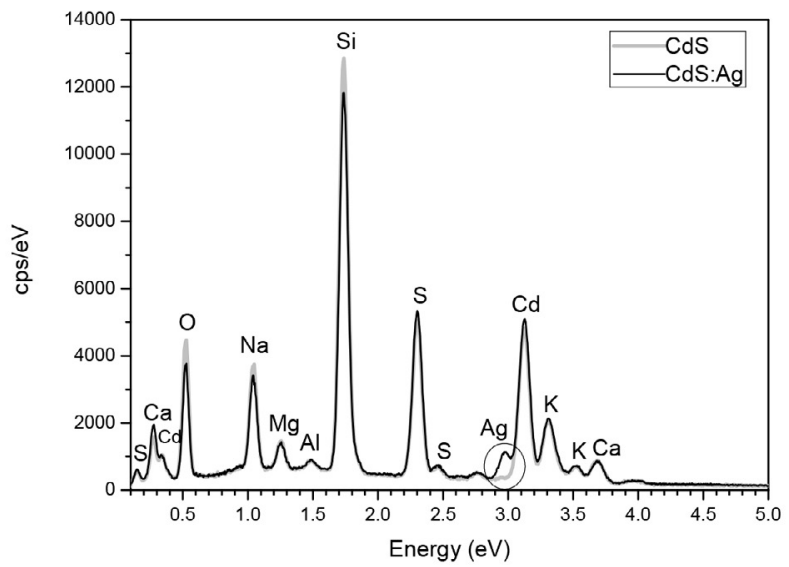

Figure 6. EDS measurements of CdS (gray solid line) and silver coated CdS (black solid line) thin films.

In the case of the silver coated CdS thin film, signals corresponding to the elements aforementioned were present. In addition, a signal corresponding to the energy of silver at $2.98 \mathrm{KeV}$ arose. This characterization enhances the slight difference between both systems of thin films. This justifies a surface difference in chemical composition.

Table I lists EDS measurements (mass \%) and the calculated atomic percentages of the elements labeled on Figure 6. The study focused on the next elements: carbon, oxygen, sodium, silicon, sulphur, cadmium and silver. Sulphur and cadmium percentages almost remained constant on both films. However, in the thin film immersed in a colloidal silver suspension, an atomic percentage of silver of 1.90 $\%$ emerged. In comparison to the work of Shah et al. a similar trend in composition for the EDS was observed. ${ }^{19}$

Table I. EDS measurements: mass and atomic percentages.

\begin{tabular}{ccccc}
\hline & \multicolumn{2}{c}{ CdS } & \multicolumn{2}{c}{ CdS:Ag } \\
Element & Mass (\%) & Atoms (\%) & Mass (\%) & Atoms (\%) \\
\hline $\mathrm{C}$ & 3.93 & 11.25 & 4.50 & 13.44 \\
$\mathrm{O}$ & 12.8 & 27.53 & 10.44 & 23.39 \\
$\mathrm{Na}$ & 4.07 & 6.09 & 4.09 & 6.37 \\
$\mathrm{Si}$ & 21.68 & 26.56 & 20.72 & 26.45 \\
$\mathrm{~S}$ & 9.89 & 10.61 & 9.79 & 10.94 \\
$\mathrm{Cd}$ & 42.76 & 13.09 & 40.39 & 12.88 \\
$\mathrm{Ag}$ & - & - & 5.71 & 1.90 \\
Others & 4.87 & 4.87 & 4.36 & 4.63 \\
\hline
\end{tabular}

The next characterization is XRD. Figure 7 compiles the XRD patterns for CdS and CdS:Ag. The identified planes indicated on the figure are: (002), (101), (103) and (112). These correspond to hexagonal CdS (PDF\# 411049). As it can be appreciated, the pattern for the silver coated CdS film is mildly more defined. This enhancement could be due to the silver clusters deposited on CdS. From the CdS pattern we calculated the crystallite size () by using the Debye-Scherrer equation.

$$
c_{s}=\frac{0.9 \lambda}{\beta \cos \theta}
$$

Where is the used X-ray wavelength $=1.5418 \AA$; is the full width at half maximum (FWHM) of the main peak, $0.0108 \mathrm{rad}$ and is half of angular value at the peak location in the diffraction pattern, .

$$
\begin{aligned}
c_{S} & =\frac{0.9(1.5418 \AA)}{0.0108\left(\cos 13.36^{\circ}\right)}=132.057 \AA \\
& =13.2057 \mathrm{~nm}
\end{aligned}
$$

This crystallite size was obtained utilizing the XRD for the CdS thin film.

Finally, Figure 8 presents the comparison of the Raman dispersion spectra. The black curve shows sequential disperson bands of low amplitude, without well defined peaks. On the other hand, when the CdS layer was coated with silver, the Raman dispersion spectrum was modified significantly at $293.3 \mathrm{~cm}^{-1}$ (first order longitudinal optic mode 1LO), where the peak is significantly higher than that of the CdS thin film, represented by the gray curve. This behavior has been reported on the literature. ${ }^{15}$ The fundamental modification consists on an extreme magnification on the 1LO dispersion due to the SERS (sur- 


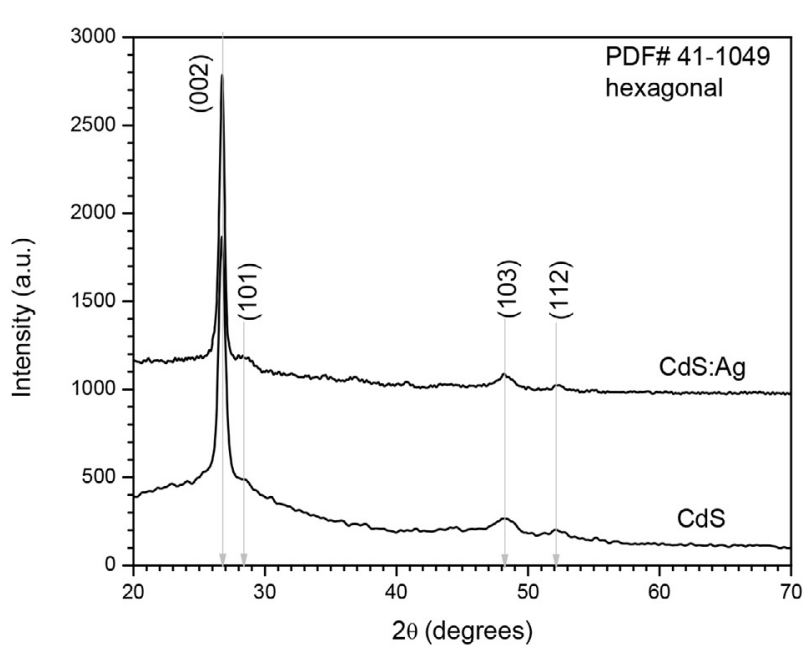

Figure 7. XRD patterns for CdS (lower) and silver coated CdS (upper) thin films.

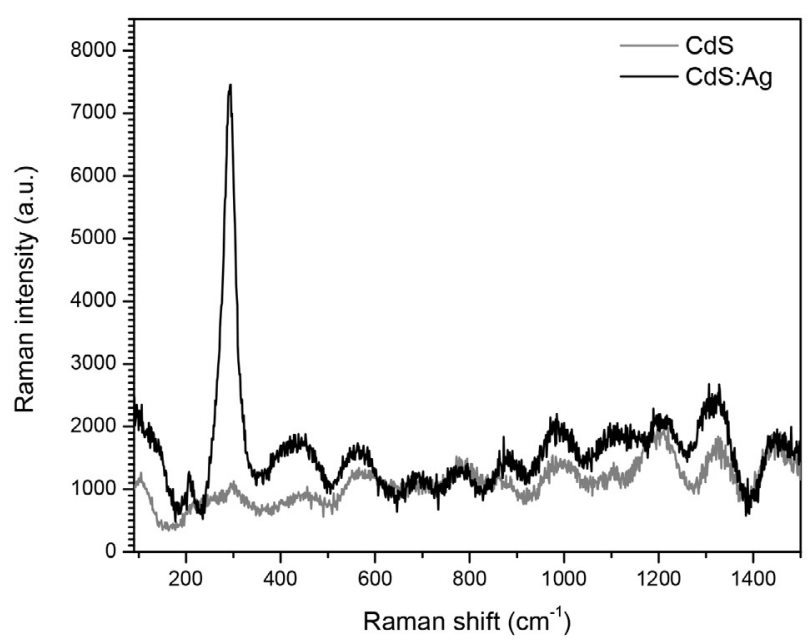

Figure 8. Raman dispersion spectra of CdS (gray solid line) and silver coated CdS (black solid line) thin films.

face-enhanced Raman scattering) effect. Similar results were obtained in the literature. ${ }^{19}$

\section{Conclusions}

On the comparative study of CdS and silver coated CdS thin films slight differences on their properties were observed. The most important differences were the formation of silver discrete aggregates and the SERS effect on the Raman characterization. In addition, the absorption and transmission properties varied slightly from 492 to 894 $\mathrm{nm}$, causing the band gap to decrease in only $0.01 \mathrm{eV}$. XRD studies did not detect the presence of silver.

\section{References}

1. M. Isshiki, J. Wang, II-IV Semiconductors for Optoelectronics: CdS, CdSe, CdTe. In: S. Kasap, P. Capper (Ed.)
Springer, Cham. 2017, 853-865.

DOI:10.1007/978-3-319-48933-9_33

2. J. M. Kephart, R. M. Geisthardt, W. S. Sampath, Prog. Photovolt. 2015, 23, 1484-1492. DOI:10.1002/pip.2578

3. M. F. Rahman, J. Hossain, A. Kuddus, S. Tabassum, M. H. K. Rubel, H. Shirai, A. B. M. Ismail, Appl. Physics A. 2020, 126, 145:1-11. DOI:10.1007/s00339-020-3331-0

4. A. Pramanik, A. K. Datta, S. Gupta, B. Ghosh, D. Das, D. V. Kumbhakar, Int. J. Res. Pharm. Sci. 2017, 8, 741-753.

5. S. Sarkar, A. D. Jana, S.K. Samanta, G. Mostafa, Polyhedron 2007, 26, 4419-4426.

DOI:10.1016/j.poly.2007.05.056

6. H. Pengchen, L. Bing, F. Lianghuan, W. Judy, J. Haibo, Y. Huimin, X. Xinju, Surf. \& Coat. Technol. 2012, 213, 84-89.

7. W. P. Mc Cray, Nature Nanotech 2007, 2, 259-261. DOI: $10.1038 /$ nnano.2007.121

8. M. A. Buckingham, A. L. Catherall, M. S. Hill, A. L. Johnson, J. D. Parish, Cryst. Growth Des. 2017, 17, 907-912. DOI:10.1021/acs.cgd.6b01795

9. K. Mokurala, L. L. Baranowski, F. W. de Souza-Lucas, S. Siol, F. A. Maikel, M. van Hest, S. Mallick, P. Bhargava, A. Zakutayev, ACS Combinatorial Sci. 2016, 18, 583-589.

DOI:10.1021/acscombsci.6b00074

10. M. F. Rahman, J. Hossain, A. Kuddus, M. M. A. Moon, A. B. M. Ismail, SN App. Sci., 2, 590:1-12.

11. S. J. Castillo, A. Mendoza-Galvan, R. Ramirez-Bon, F. J. Espinoza-Beltrán, M. Sotelo-Lerma, J. González-Hernández, G. Martínez, Thin Solid Films, 2000, 373, 10-14.

DOI:10.1016/S0040-6090(00)01080-4

12. A. de Leon, M. C. Acosta-Enriquez, S. J. Castillo, D. Berman-Mendoza, A. F. Jalbout, J. Molec. Struct.: THEOCHEM, 2010, 951, 34-36. DOI:10.1016/j.theochem.2010.04.003

13. A. Apolinar-Iribe, M. C. Acosta-Enriquez, M. A. Quevedo-Lopez, R. Ramirez-Bon, S. J. Castillo, Chalc. Lett. 20118 , 77-82.

14. M. Ruiz-Preciado, M. A. Quevedo-Lopez, A. G. Rojas-Hernandez, A. de Leon, A. Apolinar-Iribe, R. Ochoa-Landin, G. Valencia-Palomo, S. J. Castillo, Digest J. Nanomater. and Biostruct. 2017, 12, 1057-1067.

15. S. Rengaraj, S. H. Jee, S. Venkataraj, Y. Kim, S. Vijayalakshmi, E. Repo, A. Koistinen, M. Sillanpää, J. Nanosci. Nanotechnol. 2011, 11, 2090-2099. DOI:10.1166/jnn.2011.3760

16. X. Chao, S. Ming-Ming, S. Hua-Tian, M. Strømme, Z. QianFeng, Dalton Trans. 2019, 48, 5505-5510. DOI:10.1039/C9DT00480G

17. T. Zhai, X. Fang, L. Li, Y. Bando, D. Golberg, Nanoscale 2010, 2, 168-187. DOI:10.1039/b9nr00415g

18. J. Kaur, R. Kaur, S. K. Tripathi, Acta Metallurgica Sinica (Eng. Lett.) 2019, 32, 541-549.

DOI:10.1007/s40195-018-0824-3

19. N. A. Shah, A. Nazir, W. Mahmood, W. A. A. Syed, S. Butt, Z. Ali, A. Maqsood, J. Alloys and Compounds 2012, 512, 27-32. DOI:10.1016/j.jallcom.2011.08.081

20. J. Tauc, Mater. Research Bull. 1968, 3, 37-46. DOI:10.1016/0025-5408(68)90023-8 


\section{Povzetek}

$\mathrm{V}$ delu je opisana priprava tankih filmov kadmijeveda sulfida (CdS) z metodo sinteze plasti iz raztopin in nalaganjem prevleke iz delcev srebra (CdS:Ag). Merili smo absorpcijske in transmisijske odzive. Izračunane širine prepovedanega pasu so 2.50 (CdS) in $2.49 \mathrm{eV}$ (CdS:Ag). Z metodo vrstične elektronske mikroskopije smo opazovali tvorbo skupkov granularne oblike. Pri največji povečavi 50000x smo opazili granulate srebrovih skupkov in jih karakterizirali z elementnim mapiranjem pri povečavi 18000x. Energijsko disperzijska spektroskopija (EDX) je pokazala razliko med srebrovimi skupki in tankim filmom CdS. Rentgenska difrakcija je pokazala samo vrhove CdS, ne pa tudi srebra. Velikost kristalitov je približno $13 \mathrm{~nm}$. Ramansko sipanje na srebrovi prevleki CdS filmov smo opazili pri $293.3 \mathrm{~cm}^{-1}$. 